\title{
Uma incursão à pré-história brasileira
}

Carolina Limonge Cavlac ${ }^{1}$

\author{
CAVLAC, C.L. Uma incursão à pré-história brasileira. Lopes, R.J. 2017. 1499: o Brasil antes \\ de Cabral. Harper Collins, Rio de Janeiro. 246 pp. R. Museu Arq. Etn. 31: 131-134, 2018.
}

Este livro do jornalista Reinaldo José Lopes, publicado em 2017, é uma incursão ao universo pré-histórico da região hoje chamada Brasil. Ele publicou outros livros de divulgação científica: Além de Darwin (2009), Os 11 maiores mistérios do universo (2014), Deus: como Ele nasceu (2015), Luz, ciência e muita ação (2016) e Darwin sem frescura (2019). Lopes é também repórter, colunista e blogueiro do jornal Folha de S.Paulo. É autor do blog Darwin e Deus e youtuber, com o canal "Reinaldo José Lopes - Darwin Deus Tolkien Mozart". Além de escrever sobre história e pré-história, Lopes tem grande interesse por narrativas de ficção com temas medievais e as influências histórico-culturais que as permeiam.

Nesta obra, Lopes traz informações para um público abrangente, que vai de curiosos não acadêmicos a estudiosos de várias áreas de conhecimento - arqueologia, história, antropologia, sociologia, paleontologia, biologia, geologia, geografia etc. Ele oferece um texto de leitura fluida, com muito bom humor e embasamento científico. Com incursões explicativas, nas seções "explicação técnica" aborda assuntos específicos, como datação radiocarbônica, análise genética e isotópica, e deriva linguística, incluindo ainda assuntos mais complexos e que não são o tema central da narrativa, deixando o leitor inteirado do que há por vir.

Na introdução "O passado não é mais como era antigamente", o autor trata brevemente de alguns dos principais temas

* Doutoranda em Desenvolvimento Sustentável, no Centro de Desenvolvimento Sustentável, da Universidade de Brasília.<ina.cavlac@gmail.com> abordados no livro: a chegada dos seres humanos nessa região onde é hoje o território brasileiro, as hipóteses sobre essa chegada e as descendências dos povos nativos atuais, a famosa Luzia (nome dado ao fóssil humano mais antigo encontrado na América do Sul, de uma mulher, que foi descoberto numa gruta da Lapa Vermelha/MG), as comunidades criadoras dos sambaquis, o surgimento da agricultura da Amazônia, a chamada "terra preta de índio", algumas sociedades pré-históricas que se estenderam da Amazônia central até o litoral oceânico e em direção ao Alto Xingu, a complexidade linguística registrada nesse território e uma contextualização do limiar entre a pré-história e a história propriamente dita. $\mathrm{O}$ autor trata de uma questão genética, comentando algumas pesquisas que abordam a descendência da população brasileira atual, incluindo a dos povos nativos, mostrando que no Brasil também ocorreu o padrão de colonização humana amplamente difundido no mundo:

os homens dos grupos vencidos são mortos ou escravizados, e as mulheres viram concubinas. [...] Para ser mais exato, entre 20\% e 30\% dos brasileiros vivos hoje descendem de uma tataravó índia, como mostra o mtDNA (DNA mitocondrial). Enxergar com mais clareza a ascensão e queda de povos e culturas do Brasil pré-histórico abre, portanto, uma janela com vista para o passado familiar remoto de quase todos nós (Lopes 2017: 23).

Finaliza a introdução trazendo uma questão para seus leitores: como o que está 
sendo descoberto sobre a pré-história do antigo território do Brasil pode ter implicações no modo de vida que temos hoje?

No capítulo um, "Quem é você, Luzia?" o autor traça um contexto "pré-histórico" faunístico da cena sul-americana há cerca de 12 mil anos, quando viveu Luzia. Ossadas de muitos exemplares da megafauna extinta encontradas nessa região e em outros locais do Brasil, como as preguiças gigantes (Catonyxcuvieri, Eremotheriumlaurillardi), o dente-de-sabre (Smilodonpopulator), os tatus gigantes, conhecidos como gliptodontes, os toxodontes, parecidos com o hipopótamo, e macrauquênias, parecidas com lhamas de tromba. $\mathrm{O}$ autor foi bem feliz na contextualização da megafauna, mas o achei bem diplomático ao tratar da extinção desses grandes mamíferos, mantendo-se longe da discussão atual da ciência: mudanças climáticas versus ação antrópica/caça. Ele comenta também a colonização das Américas por (outros) primatas e roedores, e o intercâmbio faunístico entre as Américas do Norte e do Sul.

Grande parte da discussão sobre Luzia gira em torno da polêmica sobre os traços africanos de seu rosto. Lopes mostra informações de pesquisas genéticas com dados moleculares de outros paleoíndios, de populações pré-históricas nativas com morfologia mongoloide e dos povos nativos atuais, e esmiúça as hipóteses da origem dos paleoíndios e desses traços, que apresentam morfologia autralomelanésia (negra) em contraste com a morfologia mongoloide (traços asiáticos) dos nativos atuais e de nativos pré-históricos mais recentes. Justifica ter mantido a narrativa na região de Lagoa Santa por ter mais informações diretas e dados mais consensuais. Lopes comenta ligeiramente os vestígios dos sítios arqueológicos encontrados no Parque Nacional da Serra da Capivara/PI e a contradição entre as possíveis datações desses sítios, propostas por diferentes pesquisadores. Porém, a enorme coletânea de sítios que apresentam inscrições rupestres e material lítico atualmente no Brasil me deixa a sensação de que Lopes poderia ter explorado o assunto muito mais.
No capítulo dois, "As conchas e os mortos", Lopes discute a cultura e os modos de vida dos antigos habitantes do litoral brasileiro, os criadores dos "morros de conchas" conhecidos como sambaquis. Para que serviam? Que tamanho têm? Em quanto tempo esses povos os construíam? De que são feitos? Quão abrangente se tornou essa cultura na costa do Brasil? O autor tenta responder essas e outras perguntas citando pesquisas atuais, que curiosamente se valeram da exploração mineradora irregular dos séculos anteriores, que usou os sambaquis como matéria-prima para a construção civil. Sem querer, essa exploração revelou (juntamente com pesquisas arqueológicas) informações cruciais sobre a cultura e ecologia dos povos dos sambaquis.

O capítulo três, "Revolução agrícola made in Brazil", funciona como uma coletânea de informações sobre a temática do manejo e cultivo de vegetais nativos da região amazônica. Trata do surgimento de florestas antropogênicas e das plantas nativas domesticadas, como a mandioca, a pupunha, o abacaxi e o cacau, e traça algumas possíveis rotas de domesticação, como a difusão da mandioca da Amazônia até o Pacífico, e do milho, domesticado na região do México e espalhado pelas Américas.

Os modos de vida dessas sociedades, que passam a ter uma diversidade de alimentos manejados ou cultivados, formam um elo com as informações e hipóteses abordadas sobre a "terra preta de índio" encontrada em muitos locais da Amazônia.

Nos capítulos quatro ("Os filhos da serpente") e cinco ("No reino das Amazonas") o autor trata das culturas dos antigos marajoaras, povo que residiu na Ilha de Marajó e dos povos de diversos outros locais na Amazônia, respectivamente. De cerca de 2 mil a.C. aos primeiros séculos da Era Cristã, o autor identifica o crescimento da densidade populacional como indicador para tratar da complexidade social, política e cultural dessas sociedades estabelecidas ao longo do Rio Amazonas. Os antigos marajoaras aproveitavam as condições do ambiente, como a topografia, o clima, o solo e a maré, para criar intervenções em seu ambiente natural, como os 
tesos, morros artificiais criados para formarem lagos rasos que armadilhavam uma grande variedade de peixes nas "cheias".

A complexidade das intervenções do ambiente natural e da produção da cerâmica marajoara marcou a cultura e o modo de vida desse povo. Nos arredores da atual Santarém se estabeleceu o domínio dos Tapajós. Descritos como um povo guerreiro e com uma poderosa chefia ribeirinha, os Tapajós também possuíam ampla diversidade de cultura material, abrangendo artefatos em madeira, algodão e cerâmica, como os muiraquitãs, estatuetas replicadas e bem conhecidas hoje. No atual território do Amapá, a cultura Maracá tem instigado pesquisadores, tanto por conta do sítio com estruturas megalíticas quanto das grutas descobertas com grandes quantidades de urnas funerárias antropomórficas ricas em detalhes.

Utilizadas em cerimônias religiosas, tal como os artefatos das culturas Tapajó e Marajoara, essas cerâmicas podem ser indicadores da complexidade econômica e social desses povos.

No Alto Xingu, as estruturas das aldeias pré-históricas descritas eram compostas de enormes áreas circulares, algo em torno de dez vezes maior que as aldeias atuais da mesma região. Elas possuíam áreas com lavouras de milho, mandioca, pequi e outros cultivos, assim como florestas manejadas nas proximidades da região habitada. Os antigos xinguanos dispunham de lagos artificiais e armadilhas nos cursos dos rios.

Pontes, muralhas, grandes fossos e estradas largas e limpas que cortavam as aldeias e as conectavam, também faziam parte da exímia organização estrutural que comportava milhares de moradores. Na região da atual Manaus os pesquisadores identificaram uma grande variedade de tradições de produção cerâmica, pois esses objetos são os mais preservados naquelas condições de clima.

O texto descreve algumas poucas características dos sítios associados à fase Manacapuru, à fase Paredão, à fase Axinim e à fase Guarita. Lopes menciona sítios com estruturas de defesa, como valas, paliçadas e trincheiras, que datam da mesma época em que as aldeias circulares são substituídas por povoados lineares à beira dos rios. Essas mudanças levaram pesquisadores à hipótese da ocorrência de importantes alterações socioculturais. A mais recente incógnita da Amazônia pré-histórica são os geoglifos (estruturas geométricas no solo) encontrados no atual território do Acre e do Amazonas. Essas estruturas foram descobertas recentemente por conta da intensificação do desmatamento na região. Cerca de trezentas estruturas identificadas até agora foram feitas provavelmente em uma época em que o território era muito mais densamente habitado e a floresta era manejada, com forte presença de espécies nativas úteis ao consumo humano. Apesar de dar grande ênfase à Amazônia e deixar de trazer informações importantes de sítios das áreas abertas, o autor alcança muitas "Amazônias", como citado neste trecho: "Não existe 'uma' Amazônia, mas uma imensa variedade de florestas ditas 'de terra firme' e alagadas, áreas de savanas e de campos abertos, matas mais ou menos sujeitas à seca e até uma ou outra região montanhosa” (Lopes 2017: 86).

No capítulo seis, "Tupi or not tupi", o autor descreve a diversidade linguística dos povos nativos, quão diversa pode ter sido a árvore linguística dessa região no passado e como ela está representada hoje. É estimado que, no contato inicial com os europeus, havia cerca de 1.500 línguas nessa região. Essa diversidade se expressa atualmente em 108 famílias linguísticas sul-americanas (de um total de 420 no mundo). Essa diversidade é inigualável em qualquer outra região do planeta. Os principais grupos linguísticos tratados nesse capítulo são: (1) o Aruak, com aproximadamente sessenta línguas atuais, espalhadas na América Central, Pantanal e Chaco, além da Amazônia; (2) o Tupi, com perto de quarenta línguas, ocupando áreas enormes do Brasil, em especial no litoral e na Amazônia; (3) o Carib, com cerca de trinta línguas, espalhadas pela parte norte da Amazônia, Xingu e algumas ilhas do Caribe; e (4) o Macro-Jê, que soma entre vinte e trinta línguas, que hoje ocupam regiões abertas (o Cerrado) ao sul da Amazônia e áreas de mata de araucária de São Paulo e da Região Sul do Brasil. O autor relata um pouco da cultura e 
distribuição dos povos falantes dessas línguas, as relações entre eles, com o ambiente e com os europeus. Comportamentos diplomáticos, com relativo pacifismo, habilidades de navegação, boas redes de trocas, alianças matrimoniais intergrupos, generosidade e habilidade de fala se contrapõem a comportamentos de agressividade, com ideologia bélica, rituais antropofágicos, dominação de novos territórios com ciclos intermináveis de vingança. Esses são comportamentos culturais descritos de alguns povos nativos da época da colonização, que representam as extremidades de uma palheta muito diversa e complexa da estrutura cultural dessa grande quantidade de povos.

Por fim, no epílogo, "Por que o Brasil préhistórico foi derrotado", o autor conta como uma região habitada por cerca de 8 milhões de pessoas não impediu a colonização ou por que essa colonização não ocorreu de outra forma. Entre os maiores culpados desse roteiro, estão as reações biológicas que levaram às epidemias. A falta de contato dos nativos com muitos dos micro-organismos trazidos pelos europeus e seus animais causou devastações populacionais generalizadas nos grupos nativos, muito mais do que a presumível superioridade bélica dos portugueses e espanhóis e o uso da cavalaria. Também foi marcante a desconexão da comunicação e a (des)organização entre as chefias dos grupos nativos, quando havia chefias, frente à organização estatal dos europeus ao longo do processo. Assim, a dominação e a expansão das áreas conquistadas pelos europeus foram aumentando, como mostra nesse trecho: "muitas das sociedades ameríndias do litoral ficavam cada vez mais desarticuladas diante das epidemias, da conversão religiosa e das exigências de mão de obra dos colonizadores - uma desarticulação demográfica, política e cultural que provavelmente foi sendo transmitida pouco a pouco" (Lopes 2017: 227).

O livro de Lopes aborda a arqueologia do território brasileiro e cumpre muito bem o seu papel de obra de divulgação científica, com a explanação das muitas pesquisas que envolvem o tema. Como não poderia deixar de ser, traz muito mais dúvidas do que certezas, de forma elegante. Apesar de ter deixado de abordar centenas de sítios com inscrições rupestres e com material lítico de que temos registros hoje, a obra contribui muito para a importância da arqueologia dessa parte do mundo, ainda tão pouco explorada. Prova disso é a frase final do livro: "A pré-história é a chave para entender a importância dessas condições iniciais e para demonstrar - como espero ter demostrado - que o passado profundo do Brasil é tão rico e complexo quanto o do Velho Mundo. Em nome dos que são herdeiros dele, convém não esquecê-lo" (Lopes 2017: 232). Lopes finaliza assim o livro, mostrando mais uma vez, com excelência, que debruçar o olhar curioso e metódico sobre o passado pode também apontar direções para o futuro.

\section{Referências bibliográficas}

Lopes, R.J. 2017. 1499: o Brasil antes de Cabral. Harper Collins, Rio de Janeiro. 